\title{
Necrològica: Basil Bernstein
}

\author{
Xavier Bonal \\ Universitat Autònoma de Barcelona. Departament de Sociologia \\ 08193 Bellaterra (Barcelona). Spain
}

La mort de Basil Bernstein (1924-2000) ens ha deixat orfes d'un dels més grans teòrics de la sociologia de l'educació. El seu treball mostra, sens dubte, una trajectòria professional coherent $\mathrm{i}$ consistent, centrada en una sòlida línia d'investigació, on cada treball demostra de sobra el valor afegit que incorpora. Des de la seva incorporació l'any 1963 a la Universitat de Londres, Bernstein va centrar la seva recerca teòrica i empírica a mostrar les formes en què les relacions de poder i control social són configuradores i estructuradores de les identitats i experiències individuals en les relacions de comunicació pedagògica. La seva recerca contribueix, així, a omplir un dels buits més significatius de la sociologia de l'educació contemporània, especialment en l'àmbit de les teories de la reproducció: com les relacions socials externes a les institucions de comunicació pedagògica estructuren les diverses formes de transmissió cultural i configuren les microrelacions socials en la interacció quotidiana. És secundari el fet que aquesta transmissió tingui lloc a les institucions de la família, l'escola o qualsevol altre camp de control simbòlic, tot i que se sap que Bernstein va estudiar a bastament les dues primeres. El que realment és rellevant per a ell és esbrinar la gramàtica intrínseca del missatge, una gramàtica que respon a relacions socials i és portadora de formes de poder i principis de control.

La seva heterodoxa obra el duu a servir-se d'autors tan diversos com Durkheim, Mead, Marx, Chomsky o Piaget, per citar-ne només alguns. És el seu treball el que dóna coherència a autors de naturalesa tan diversa. Bernstein se serveix de Durkheim per esclarir la relació entre els ordres simbòlics, les relacions socials i l'estructuració de l'experiència. Concretament, a partir de l'obra de Durkheim, Bernstein pot relacionar els canvis en la divisió social del treball amb les estructures i formes d'organització de les institucions, basant-se en formes de solidaritat mecànica i orgànica, i distingir, així, entre orientacions posicionals o personals en les relacions socials. En Marx troba la base explicativa del desenvolupament i canvi de les estructures simbòliques i de la importància social del sistema productiu. Recorre a Mead per entendre com aquestes estructures de poder són configuradores del «jo social» i, per tant, de l'estructuració de l'experiència. De Chomsky, tot i les seves desavi- 
nences, pren la distinció entre el sistema de regles de la llengua i les regles socials que en determinen l'ús, aspecte fonamental per entendre la seva teoria dels codis sociolingüístics. En l'obra de Piaget, d'altra banda, identifica les bases d'unes formes de transmissió cultural que seran apropiades per la nova classe mitjana per impulsar les pedagogies invisibles en el sistema educatiu.

És precisament aquesta heterodòxia de la seva obra el que ha impossibilitat la classificació de Bernstein entre els diversos corrents dominants de la sociologia de l'educació, o el que ha generat l'aparició de crítiques sobre la seva orientació funcionalista, marxista o globalment estructuralista. Aquestes crítiques, al meu entendre, infravaloren la lucidesa de la seva anàlisi i la seva capacitat per establir un conjunt de conceptes útils per a la classificació de les pràctiques escolars sense desvincular-les de la base social que les regula. En efecte, un dels mèrits de Bernstein és aconseguir definir conceptes i instruments la precisió dels quals és extraordinàriament suggeridora a l'hora de fer recerca sociològica a la família o a l'escola. Per això hi ha una gran quantitat d'autors que s'han servit de la seva teoria per aproximar-se a l'estudi de les relacions socials a la família, a l'anàlisi de la transmissió educativa o a les relacions de poder que estructuren el discurs pedagògic. Les distincions entre codis de parla elaborats o restringits, entre classificació i emmarcament del coneixement educatiu, o la definició de regles distributives o de recontextualització del dispositiu pedagògic, ens permeten endinsar-nos en l'estudi del text sense perdre la referència del context social que el sobredetermina.

Després de la publicació dels tres volums de Classes, codis $i$ control als anys setanta, Bernstein no reapareix en l'escena acadèmica fins als anys noranta per regalar-nos dos llibres que completen la seva extraordinària obra. A La estruc tura del discurso pedagógico i a Pedagogía, control simbólico e identidad (ambdós editats per Morata), Bernstein hi revisa diversos aspectes del seu treball anterior per arribar a una densa teoria de les regles internes que configuren el que ell anomena el dispositiu pedagògic. Aquest dispositiu constitueix el mitjà de transmissió de la comunicació $i$ està format per regles jeràrquiques de caràcter social. Bernstein aconsegueix, així, completar una teoria de la transmissió cultural que parteix del nivell de la producció i la distribució de coneixement, passa per les instàncies de recontextualització d'aquest coneixement, i acaba en la mateixa pràctica pedagògica. Amb aquests treballs, la teoria de Bernstein s'estén més enllà de la família i l'escola per arribar a qualsevol camp de control simbòlic. Ens ofereix, per exemple, un marc teòric innovador per estudiar els processos de reforma educativa, des del moment de la planificació i experimentació fins a l'extensió i l'avaluació, i ens permet defugir visions excessivament conspiratives o massa ingènues sobre el canvi educatiu. I, potser el més important, ens proporciona noves vies d'anàlisi que poden ajudar la sociologia de l'educació a deixar l'ús de paradigmes que poca cosa més poden aportar. 